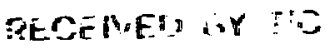

Submitted to:

Transplant. Proc.

In Vivo Lymphocyte Iransformation Induced by

$H-2 D$ and $H-2 K$ Components of the $H-2$ Locus

By DIANA M. POPP

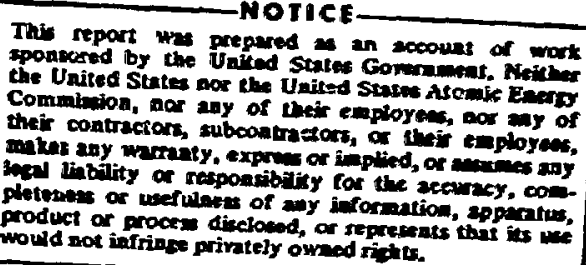

From the Biology Division, Oak Ridge National Laboratory, Oak Ridge, Tenn.

Research sponsored by the U. S. Atomic Energy Commission under contract

with the Union Cabide Corporation. 
Running head: $\quad H-2 D$ and $H-2 K$ COMPONENTS

Send proofs to: Diana M. Popp

Biollogy Division

Oak Ridge National Laboratory

P. O. Box Y

Oak Ridge, Tennessee 37830 


\title{
IN VIVO LYMPHOCYTE TRANSFORMATION INDUCED BY H-2D AND H-2K COMPONENTS OF THE H-2 LOCUS
}

\author{
By Diana M. Popp
}

Reports from several laboratories hove shown that differential immune reactivity can be induced by different portions of the $\underline{\mathrm{H}-2}$ lacus. ${ }^{1-3}$ By studying in vivo lymphocyte transformation induced by host antigens it has been possible to show that the cellular response to a non-H-2 antigen is delayed and qual ifatively different from the response to $\mathrm{H}-2$ antigens. 4,5 In the present study, in vivo lymphocyte transformation was induced by incompatibilities at different portions of the $\mathrm{H}-2$ locus in an attempt to learn more about the cellular basis of differenrial reactivity inciuced by different $\mathrm{H}-2$ deterninants. The immunegenetic effect of these insompatibilities was assessed by following the antigen-dependent proliferation of donor cells in the spleen.

\section{MATERIALS AND METHODS}

Mouse stroins used in these experiments were the congenic resistant pair $\mathrm{C} 5 \mathrm{BL} / 10 \mathrm{Sn}(\mathrm{B} 10)$ and $\mathrm{C} 57 \mathrm{BL} / 10 . \mathrm{A}(\mathrm{B} 10 . \mathrm{A})$ and the $\mathrm{H}-2$ recombinant lines

From the Biology Division, Oak Ridge National Laboratory, Oak Ridge, Tenn.

Research sponsored by the U. S. Atomic Energy Commission under controct with the Union Carbide Corporation. 
C57BL/10.A(2R) and C57BL/10.A(5R). The linear order of the $\mathrm{H}-2$ specificities that distinguish these strains ${ }^{6}$ is presented in simplified form in Fig. 1. The $2 R$ and $5 R$ lines resulted from crossovers between $\underline{H-2^{a}}$ and $\underline{H-2^{b}}$ at the positions indicated by arrows; ${ }^{6} 2 R$ received the portion of the genome to the leff of the arrow $(H-2 D)$ from $H-2^{b}$ of $B 10$ and the portion to the right of the arrow $(H-2 K)$ from $\underline{H-2^{a}}$ of $B 10 . A_{;} 5 R$ received $H-2 D$ genetic information from ${ }^{H-2^{a}}$ and the $\mathrm{H}-2 \mathrm{~K}$ segment from ${\underline{\mathrm{H}-2^{b}}}^{\mathrm{b}}$. Therefore, when $2 \mathrm{R}$ or $5 \mathrm{R}$ lymphocytes ore infused into B 10 recipients the donor cells can respond only to the $\mathrm{H}-2 \mathrm{~K}$ or $\mathrm{H}-2 \mathrm{D}$ determinants, respectively. B10.A recipients of $2 R$ or $5 R$ lymphocytes present only $H-2 D$ or $\mathrm{H}-2 \mathrm{~K}$ incompatibilities, respectively, to the donor cells. Using these four strains, various combinations can be mode to analyze the ability of individual or combined H-2 specificitios to induce in vive lymphon;te transformation.

After lethal irrodiation $(850 \mathrm{r}$ ), recipient mice were given introvenous injections of $50 \times 10^{6}$ viable lymph-node lymphocytes. Donoss and recipients were matched for sex. Spleens were removed daily, fixed in Camoy's, and stained with methyl green pyronin. Three to five thousand nucleated cells per spleen were scored for mitotic figures and large pysoninophilic cells (LPC). Areos scanned were limited to regions where transformation was occurring, since the time and magnitude of transformation were the critical points. 


\section{RESULTS}

The percentage of LPC and the mitotic index (Mi) for doys $1-6$ for the isologous, $\mathrm{H}-2$-incompatible, and H-2D- or H-2K-incompatible combinations in B10 recipients are plotted in Fig. 2. The isologous combination establishes baseline values of cellular activity in the absence of tissue antigen differences. The curves for the three allogeneic combinations show a marked increase in cellular activity, well above that of the isologous control. H-2 incompatibility results in an immediate increase in cellular activity, reaching a maximum at day 3 , when about $30 \%$ of the nucleated cells in the regiors of iransformation are LPC, and on day 4 , when the $M I$ is $3.6 \%$. The response to the $\mathrm{H}-2 \mathrm{~K}$ incompatibility parallels the response to $\mathrm{H}-2$, peaking at doy 4 , although the percentage of LPC seen in the transforming regions is consistently lower from days 3-6. In controst, there is no significant cellular transformation or mitotic activity induced by $\mathrm{H-2D}$ incoinpatibility through doy 3 , when only a small number of LPC and mitotic figures appear in the presumptive transformation regions. Cellular activity is greatest on day 5 , when the percentoge of LPC is double and the MI is triple the values recorded for day 4.

Seven combinations were analyzed to compare the responses induced by different $\mathrm{H}-2 \mathrm{D}$ and $\mathrm{H}-2 \mathrm{~K}$ specificities or similar segments from different strains. Curves generated from these combinations are shown in Fig. 3. Curves representing the cellular response induced by the $\mathrm{H}-2 \mathrm{D}$-incompatible combinations $\mathrm{B} 10 . \mathrm{A} \rightarrow 2 \mathrm{R}$ (anti-H-2.2), $2 R \rightarrow B 10 . A$ (anti-H-2.4, 13), and B10 $\rightarrow 5 R$ (anti-H-2.4, 1j,3), together with the 
curve established for the basic $\mathrm{H}-2 \mathrm{D}$-incompatible combination $5 \mathrm{R}-\mathrm{B} 10$ (anti-H-2.2), are shown in Fig. 3a and b. All H-2D-incompatible combinations induce a similar cellular response, except for the response induced by the $H-2,4,13,3$ segment, which is immediate and peaks ot day 4. The curves representing the cellular response induced by three different $\mathrm{H}-2 \mathrm{~K}$-incompatible combinations are plotted together (Fig. 3e and d) and are not significantly different.

\section{DISCUSSION}

There is ample evidence that cellular cooperation between two cell populations occurs during the antibody response to certain protein antigens. ${ }^{7}$ The interactions between these two populations, thymus-derived (T) and bone-marrow-derived (B) celis, and antigen involve specificity. ${ }^{8}$ The nature of the interaction of antigenic determinants and cells and subsequently the cell-to-cell interaction is uncleor, 9 and even less is known of the complex events which occur during the response to histocompotibility antigens. A few reports hove suggested that not all determinants of the major $\underline{H}$ loci function alike, ${ }^{5,10-12}$ but the basis for the difference remains unclear. Data reported here show that the cellular activity induced by $\mathrm{H}-2 \mathrm{~K}$ determinants has the same time course as an $\mathrm{H}-2$ response but oppears to be reduced in magnitude. $\mathrm{H}-2 \mathrm{D}$ determinants, nonstimulators in $\mathrm{MLC}^{11}$, will induce on in vivo lymphocyte response, al though it is markedly different from the one induced by $\mathrm{H}-2 \mathrm{~K}$ determinants. The response to $\mathrm{H}-2 \mathrm{~K}$ determinants is greatest on days 3 and 4 and declines by day 5 , when the response to H-2D determinants is the greatest. 
The differential response to $H-2 D$ and $H-2 K$ determinants occurs irrespective of the strain of the lymphocyte donor and recipient except in one case, $810-5 R$, which will be discussed later.

It has been shown that T-cell proliferation induced ty oxazalone occurs in the thymus-dependent regions of lymph nodes, beginming on doy 1 and reaching a peak on days 3 and 4 , and that proliferation of B cells does not occur untill day 5 (ref. 13). These times coincide with the timing of activation of lymphocytes by $\mathrm{H}-2 \mathrm{~K}$ and $\mathrm{H}-2 \mathrm{D}$ determinants. Sprent and Miller ${ }^{14}$ showed that semiallogene ic thymus cells have a peak incorporation of $\left[{ }^{3} \mathrm{H}\right]$ thymine on day 3 after injection into irradiated recipients, and that cells that respond within 2 days to tissue antigens are cortisone-resistant $T$ cells. Wagner et al. ${ }^{15}$ using a one-way MLR, also showed that the effector cells in cellular immune responses to allografts are cortisone-resistant T cells. These reports suggest that the lymphocytes which respond early (days 1-3) are $T$ cells and the cells responding on day 5 are B cells. This suggestion is supported by our observation that pretreatment of donors with cortisone does not effect the response induced by $\mathrm{H}-2 \mathrm{~K}$ determinants but abolishes the response induced by $\mathrm{H}-2 \mathrm{D}$ determinants. ${ }^{16}$ If different portions of the $\mathrm{H}-2$ complex stimulate different lymphocyte populations, the sequence of events in the immune response to tissue antigens moy be interpreted in the context of the hapten-cerrier systems, where $T$ cells are carrier-specific and the antibody-producing cells are hapten-specific. 7,17 Thus, we could consider that the serologically defined $\mathrm{H}-2$ specificities act as hoptens, fuming on B cells to produce the specific antibodies thai have been used to identify the $\mathrm{H}-2$ specificities 
as we know them. A heretofcre unidentified thymic dependent determinant(s) would provide the carrier function that turns on T cells to act as "killer cells" in cell-mediated immunity and to act as "helper cells" in inducing or enhancing the B-cell response. The appearance of the late response of $B$ cells to $\mathrm{H}-2 \mathrm{D}$ determinants is consistent with evidence that the hopten response is dose-depentent ${ }^{9}$ and the corrier effect enhances a weak or minimal response. Lilly ${ }^{18}$ has shown that $\mathrm{H}-2.2$ antigen alone does not induce detectable antibody levels.

It is of interest that the one H-2D incompatibility which induces early (T-cell) transformation, $B 10 \rightarrow 5 R$, is the reciprocal of the combination in which the $\mathrm{H}-2 \mathrm{D}$-induced late $(B$-cell) transformation was first noted, $5 R \rightarrow B] 0$. In both combinations the lymphocytes are reacting to allelic segments of the $\mathrm{H}-2$ locus. BlO has a determinant that can induce ear!y transformation, as seen in the combisctios $29-9 ! 0$, but it apparently resides at a position to the right of H-2.5 in the locus (fig. 1). However, the segment of $\underline{\mathrm{H}-2^{\circ}}$ that $5 \mathrm{R}$ obtained in the crossove: contains a determinant that will induce early transformation of B10 cells. Therefore, the thymic dependent determinant(s) does not appear to occupy an allelic position(s) in all $\mathrm{H}-2$ loci. The one serologically identifiable difference on $5 R$ cells determined by this segment is $\mathrm{H}-2.3$. Shreffler ${ }^{6}$ has suggested that $\mathrm{H}-2.3$ evolved from the $\mathrm{H}-2 \mathrm{~K}$ region through o postulated inverted duplication centering around $S_{s-S I_{p}}$, and it is tempting to speculate that $\mathrm{H}-2.3$ is the factor; but it is equally likely that the determinant is a nonserologically defined structure whose existence is signaled by its unique capacity to turn on $\mathrm{T}$ cells. Benoceraff et al. ${ }^{19}$ hove suggested that the Ir-1 locus 
may be a thymus receptor site, but in this instance the $\underline{\operatorname{Ir}-1}$ alleles are identical. 6 Although the Slp alleles differ in this combination, T-cell activation occurs in combirations where the Slp alleles are in common.

The data presented here show that the antigenic sites determined by different portions of the $\mathrm{H}-2$ locus function differently in the immune response. Determinants of $\mathrm{H}-2 \mathrm{D}$ segments of the $\mathrm{H}-2$ locus induce lymphocytes to transform later thon determinant(s) of the H-2K segments. Factors such as the time of the response and the sensitivity of the H-2D-induced response to cortisone suggest that a determinant(s) located in the H-2K region stimulates $\mathrm{T}$ cells and $\mathrm{H}-2 \mathrm{D}$ segments lacking this determinant stimulate $B$ cells. It is further suggesfied that the total product of the $\underline{\mathrm{H}-2}$ locus may react in the immune response much like the synthetic hapten-carrier antigens in inducing a synergistic reaction betwesn two populations of lymphosytes, resulting in an immune response characterized by cell-mediated immunity and antibody production. 


\section{REFERENCES}

1. Rychlikova, M., Demant, P., and Ivanyi, P.: Folia Biol. 16:218, 1970.

2. Demant, P.: In lengerova, A., and Vojtiskova, M. (Eds.): Proc. Symp. Immunogenetics of the H-2 System. Basel, Karger, 1971, P. 194.

3. Bonmassan, E., Goldin, A., and Cudkowicz, G.: Transplantation $12: 314,1971$.

4. Popp, D. M., and Davis, M. L.: Tramsplantation Proc. 3:187, 1971.

5. Popp, D. M., and Davis, M. L.: In Lengerova, A., and Vojtiskovo, M. (Eds.): Proc. Symp. Immunogenetics of the H-2 System. Basel, Karger, 1971, p. 182.

6. Shreffler, D. C.: In Aminoff, D. (Ed.): Blood and Tissue Antigens. New York, Academic, 1970, p. 85.

7. Mitchison, N. A., Rajewsky, K., and Toylor, R. B.: Developmental Aspects of Antibody Formotion and Structure, Vol. 2. New York, Acodemic, 1970, p. 547.

8. Paul, W. E., and Davie, J. M.: In Proc. Second Intemational Convocation of Immunuiogy. Basel, Karger, 1970, p. 116.

9. Mitchison, N. A.: In Vitro 7:88, 1971.

10. Yunis, E. J., and Amos, D. B.: Proc. Nat. Acod. Sci. U.S.A. $68: 3031,1971$.

11. Rychlikova, M., Demant, P., and Ivanyi, P.: Noture New Biol. $230: 271,1971$. 
12. Amos, D. B., and Yurnis, E. 1.: Cell. Immunol. 2:517, 1971.

13. Davies, A. J. S., Carter, R. L., Leschars, E., and Walfis, V. J.: Immunology 17:111, 1969.

14. Sprent, J., and Miller, J. F. A.P.: Cell. Immunol. 3:361, 1972.

15. Wagner, H., Harris, A. W., and Feldman, M.: Cell. Immunol. $4: 39,1972$ 。

16. Popp, D. M.: Unpublished results.

17. Bloom, B. R.: Advan. Immunol. 13:102, 1971.

18. Lilly, F., Jacoby, J. S., and Coley, R. C.: In Lengerova, A., and Vojtiskova, M. (Eds.): Proc. Symp. Immunogenetics of the H-2 System. Basel, Korger, 1971, p. 197.

19. Benceercf, B., and MeDoritt, H. O.: Seience 175:273, 1972. 


\section{FIGURE LEGENDS}

Fig. 1. - Simplified recombination maps show ing linear order of specificities pertinent to this study. Vertical bars designate subdivisions defined by recombination, arrows the position of recombination producing $2 R$ and $5 R$ alleles, and numbers serologically defined $\mathrm{H}-2$ specificities.

Fig. 2. - Cellular activity in spleens of letholly irrodiated mice receiving isologous $(B 10-B 10), H-2-$ incornpatible $(B 10 . A-B 10), H-2 D$-incompatible $(5 R \rightarrow B 10)$, and $H-2 K$-incampatible $(2 R \rightarrow B 10)$ lymphecytes. Points represent arithmetic means $( \pm S . E$.) of the percentages of LPC ond the MI from four mice.

Fig. 3. - Cellular activity in spleens of lethally isrodiated mice receiving (a, b) H-2D-incompatible lymphocytes, $5 R \rightarrow B 10$ (anti-H-2.2), B10.A $\rightarrow 2 R$ (anti-H-2.2), $2 R \rightarrow B 10 . A$ (anti-H-2.4, 13 ), and $B l O-5 R$ (anti-H-2 $4,13,3$ ); (c, d) $\mathrm{H}-2 \mathrm{~K}$-incumpatible lymphocytes, $2 R \rightarrow B 10$ (anti-H-2.33), B10.A $\rightarrow 5 R$ (anti-H-2.33), and $5 R \rightarrow B 10 . A$ (anti-H-2. $1,8,11,23,25)$. The broken lines represent the bosic $\mathrm{H}-2 \mathrm{D}$ - and $\mathrm{H}-2 \mathrm{~K}$-incompatible response taken from Fig. 2 and are shown for comparison. 


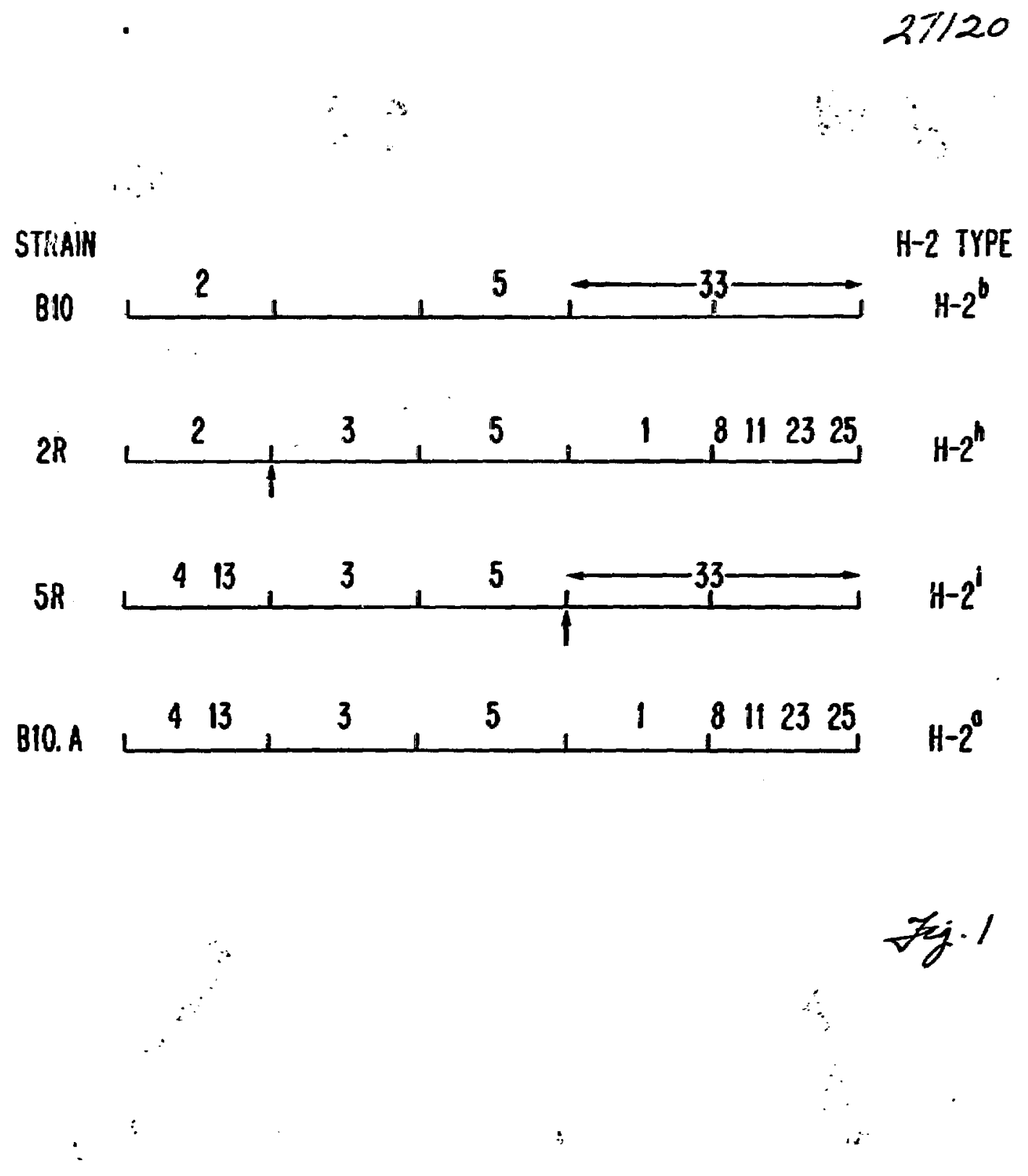


$\%$ LPC

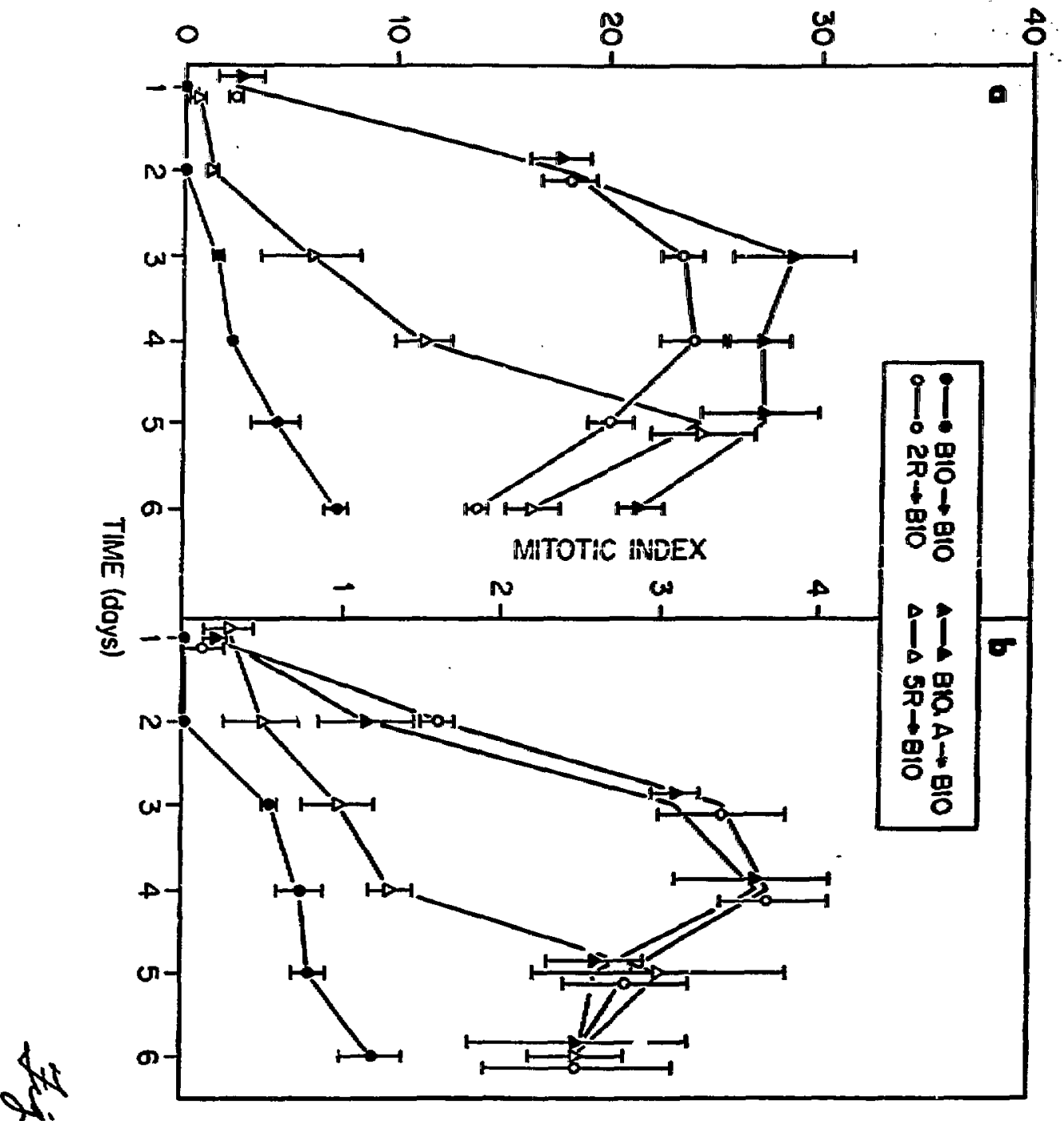




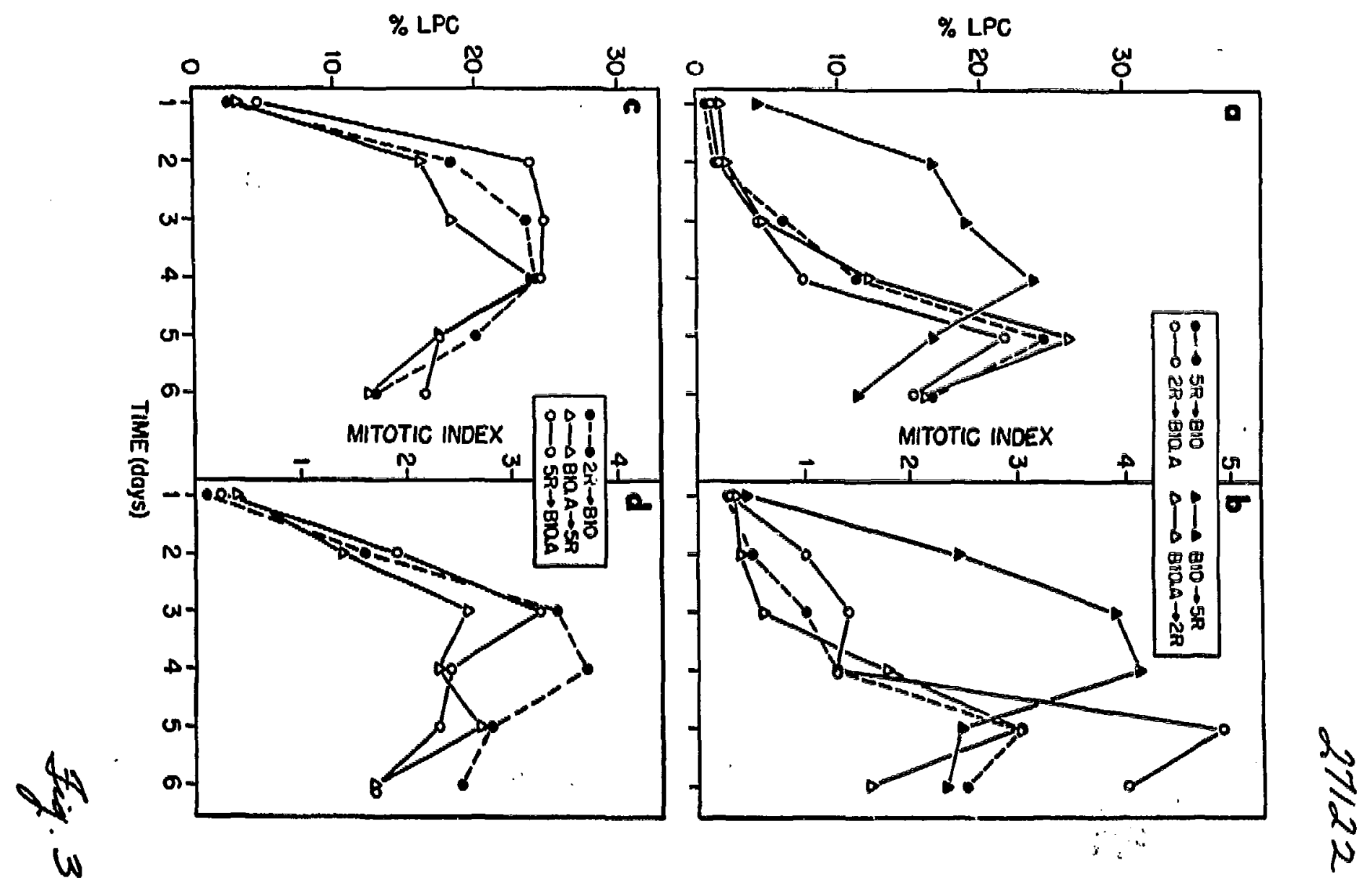

